\title{
FDI Inflow, Stock Market Performance and Exchange Rate: Indian Scenario
}

\author{
Kunal (Corresponding author) \\ Assistant Professor (Finance), Indian Institute of Management Kashipur, India
}

\author{
B V Phani
}

Professor (Finance), Department of Industrial and Management Engineering, Indian Institute of Technology Kanpur, India

Received: September 14, 2017 Accepted: September 21, 2017 Published: November 12, 2017

doi:10.5296/ijafr.v7i2.11868

URL: https://doi.org/10.5296/ijafr.v7i2.11868

\begin{abstract}
In this research work, macro level analysis has been conducted to assess impact of foreign direct investment (FDI) capital inflow in Indian economy. This study is focused on causality relationship between FDI inflow, stock market performance and foreign exchange rate. This framework is used for policy implications of relationship between three variables. These macro-economic variables are linked with different policies. Causality tests performed on these variables are further used for policy implications. Impact of change in exchange rate on changes in FDI inflow is the least significant followed by impact of changes in FDI inflow on changes in sensitivity index of stock exchange (SENSEX). The third least significant relationship is observed between changes in FDI inflow on change in exchange rate. These relationships are implied to 'Impossible Trinity' framework to assess preference for monetary, fiscal and foreign exchange rate policies. It is observed that improving performance of stock market (SENSEX) should be on priority followed by exchange rate. These finding have implications on fiscal policy, monetary policy and exchange rate. The increase in return of stock market and favourable exchange rate will help in increasing FDI inflow in Indian economy. Stock market performance depends on daily transactions by investors and they are regulated only, not controlled. Supply of foreign currency in India is controlled by the Reserve Bank of India (RBI), who assesses the supply conditions of the market and attempts to manage exchange rate in favour of Indian economy. In other words, the exchange rate can be controlled by having control on supply of foreign currency in domestic market. Hence, there is possibility of having fixed exchange rate and target band of exchange rate.
\end{abstract}




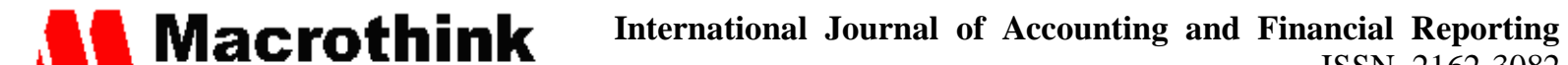 Mastion

JEL Classification: E52, E61, E62, G10, G18

Keywords: FDI, exchange rate, SENSEX, impossible trinity

The causal relationship between FDI inflow, performance of equity market and foreign exchange rate is now emerging as central issues for emerging economies, since they are designing their policy tools to increase FDI inflow, improve equity market performance and making an attempt to maintain exchange rate. Indian economy is not an exception and struggling hard to maintain exchange rate, improve performance of stock market and increase FDI inflow.

This research work is a contributing literature by reporting nature of relationship between three important macroeconomic indicators in an emerging economy like India. Implication of the observed nature of their relationship to "Impossible Trinity" framework to set priorities of different policies (fiscal, monetary and exchange rate) to be considered for improvement by host government.

Performing Granger-causality test on time series of stock market performance, FDI inflow and exchange rate, it is found that two-ways causality exists between these variables. The analysis of this causality test suggests that stock market performance and FDI inflow have positive effect on exchange rate. The reverse causality is also positive but lesser stronger. Therefore, policy maker should prefer stock market performance and FDI inflow to control exchange rate.

The finding shows that improvement of equity market (as part of monetary policy) and increasing FDI inflow (as part of fiscal policy) should be taken on priority, which will help in establishing a target band of exchange rate.

This research paper consists of seven sections. Section 1 deals with FDI inflow and equity market performance. In this section, the arguments are presented in context of Indian economy supported with facts and figures and presents hypotheses based on relationship between FDI inflow and equity market performance. Section 2 is focused on relationship between exchange rate and FDI inflow and accordingly hypotheses are presented. The central focus of section 3 is relation between exchange rate and equity market performance. This section gets concluded with hypotheses proposed for relationship between exchange rate and equity market performance. Dataset used in this research work has been discussed in section 4 while methodologies are discussed in section 5. The results and discussion is presented in section 6 and this paper is concluded with section 7 presenting conclusions and policy implications.

\section{FDI Inflow and Stock Market Performance}

\subsection{International Scenario}

Developing economy like India has realised importance of infusing foreign capital in domestic economy and accordingly foreign investors are being lured with financial and fiscal incentives. Host economy gets benefited by positive effects in terms of productivity gains, technology transfers, introduction of new processes, improved managerial skills and 


\section{Mll Macrothink}

International Journal of Accounting and Financial Reporting

ISSN 2162-3082

2017, Vol. 7, No. 2

know-how in the domestic market, employee training, international production networks, and access to markets (Encarnation \& Wells, 1985; Boddewyn, 1985). Besides these direct effects of foreign capital, their spillover effects also contribute significantly towards economic growth of the host country (Alfaro et al, 2004). Although, theoretically FDI inflow has positive impact on host economy but empirical evidences at nation level and firm level reported in literature induce ambiguity in its benefits. Aitken and Harrison (1999) observed small improvement in overall productivity of plant due to FDI. They also report that productivity of plant using FDI capital increases but it decreases for plant not using FDI capital (pure domestic). Against this backdrop, overhyped theory of 'spillover effect' is in doubt (Alfaro et al, 2004). The difference between productivity of FDI funded firms and pure domestic firm is very high in India. FDI firms has output to capital ratio of 3.55 , observed much more in comparison with the domestic firms having a ratio of 2.92 (National Council of Applied Economic Research (NCAER), 2010). This large gap in productivity of FDI firm and domestic firm, also supports doubt on spillover effect in Indian economy. Going by the international standard, it is expected to converge in long term (Romer, 1993). This convergence in emerging economy like India is issue of interest for researcher. Chakraborty and Nunnenkamp (2008) observed India's reforms have induced changes in structures and types of FDI which are relevant for the economic growth. They also report that growth impact of FDI differs across the sectors (primary, secondary and tertiary). There is weak link between FDI and output growth in the service sector, however this sector was able to attract more FDI. Manufacturing sector is getting benefited by FDI and the spillsover effect of FDI in service sector is significant. These findings are in line with other empirical evidences on 'positive impact of FDI on promoting growth' reported by Lim (2001), Lipsey (2002), OECD (2002), Khawar (2005) and Blonigen \& Wang (2004). It is interesting to note that prerequisite of getting benefited by FDI has been also reported in literature. This positive effect of FDI can't be realized by host economy unless attain a threshold level of human-capital and financial market development (Alfaro, Chanda, Kalemli-Ozcan, \& Sayek, 2004; Borensztein et al, 1998). Financial market is significant for capital accumulation and economic growth of the nation (Schumpeter, 1912). Goldsmith (1969), McKinnon (1973) and Shaw (1973) also opine that well-functioning financial market enhance economic growth of the host nation by lowering transaction cost, allocating capital to projects with highest returns. Although, source of FDI capital is foreign financial market but its spillovers depend on condition of domestic financial market. In absence of foreign financing, it is domestic financial market, which provides external finance to the firm not able to finance their project internally. The gap between current practice of the firm and new technologies used by their competitor is also important to raise fund from external sources. Alfaro et al (2004) suggest that need of external finance of a firm depends on the gap between the current practice and the new technologies. In addition to financing, financial market also helps in creation of backward linkages, which may appear in the form of emergence of a number of manufactures/suppliers etc. In India, within ten years of establishment of the Maruti Udyog Ltd. (The Govt. of India-Suzuki joint venture) a number of local manufacturers emerged to supply ancillary parts, which were initially imported from Japan. FDI is also done through merger and acquisition. In the M\&A process, financial stock market plays important role 
(especially through stock-swap) and well-functioning of stock market will facilitate stock-swap. The well-developed stock market in host economy is a link between domestic and foreign investors besides increasing the spectrum of sources of finance (Alfaro et al, 2004). The liquidity of stock market positively predicts growth, capital accumulation, and productivity improvements (Levine and Zervos, 1998). The cost of external financing also gets reduced with developed stock market (Rajan and Zingales, 1998). Stock markets helps in better allocation of investment and this lead to increase in growth even with the same level of investment (Wurhler, 2000).

\subsection{Indian Scenario}

A number of studies are reported on foreign institutional investment and stock market performance however literature is silent on impact of foreign direct investment on stock market performance.

This study is focused on mobilizing economic resources and their direction of flow using macroeconomic indicators representing the economic growth and effect of FDI inflow. Relationship between these economic indicators are analysed to establish link with stock market. On this premise, Indian scenario is being presented in two stages i.e. FDI \& economic growth and economic growth \& equity market performance.

\subsubsection{FDI and Economic Growth}

Cumulative FDI inflow in India during the period of April 2005 to Feb 2010 is 8\% (Note 1) of GDP of FY 2008-2009. The size of FDI inflow is significant as against the theory of insignificant foreign capital (Baghachi, 1983) and helps in introducing new inputs and technologies. FDI brought new technologies and inputs in India especially in automotive sectors i.e. Hyundai in Chennai, Suzuki in Gurgaon, Honda in Gurgaon etc. In the early phase, most of the parts used to be import from their home countries due to unavailability of local supplier maintaining quality standard. However, in a very short span of time, India has seen emergence of clusters of firms, capable enough to maintain international standard of quality in manufacturing automotive parts. They became suppliers to firms using FDI capital. Therefore, FDI helped in increasing level of knowledge of managers and workers. These FDI firms have also reduced market power of existing pure domestic firms. Taking these factors into consideration to endogenous growth models, FDI has positive impact on economic growth by introducing new inputs and technologies, increasing knowledge level and reducing market power of existing firms.

Degree of openness of Indian economy has increased from 14\% in 1992 (Note 2) to $41 \%$ in 2009 (Note 3). Depth of stock market in India has increased from 30\% (1992) to 102\% (2009). Depth of banking system (total deposit /GDP) in India has increased from .09\% (1992) to .13\% (2009). Credit sanctioned to commercial sector increased from $28 \%$ (1992) to $56 \%$ (2009). Literacy rate has increased from 52.21 (1991) to 64.84\% (2001). Indian trade regime is very liberal and a member of WTO. In context of India, these factors are in favour of positive impact of FDI on economic growth of India. Therefore, we expect positive growth of export oriented industrial policy, stringent regulation of deep financial market, increasing 
credit to commercial sector by banking system and high degree of openness developing Indian economy. These factors are evidence for positive effect of export oriented industrial policy. Efficiency of FDI exploitation is enhanced with better financial and banking system resulting into higher growth rate. Reserve Bank of India (RBI) and Securities and Exchange Board of India (SEBI) are making continuous effort for improving banking system and financial market systems in Indian economy. Against evidences mentioned above and reported by Alfaro et al (2004), Durham (2004) and Hermes \& Lensink (2003), Indian economy is efficiently exploiting FDI with higher growth rate.

According to market size hypothesis (Wang and Swain, 1995), Indian economy provides more opportunity to FDI assist firms to generate greater sales and profits. India, as a developing country, GDP per capita is more important than its population. Indian GDP per capita has also increased with cumulative average growth rate (CAGR) of $11.07 \%$ (from INR 7807 (1992) to INR 51737 (2009) (Note 4)). The high growth rate of GDP per capita is more important for positive impact of FDI on economy (Wheeler and Mody, 2002) and the same is expected in India.

Borghesi and Giovannetti (2003) mentioned crucial factors for host economy to have positive impact of FDI. On these factors, Indian economy can be assessed for economic growth by infusing FDI capital. India has literacy rate is $66 \%$ and gross enrolment ratio is $61 \%$ (Note 5). The tele-density is $51 \%$ (Note 6) which is considered as proxy measure for technology development. Indian economy maintains sufficiently high level on these crucial factors to capture potential benefits of FDI (OECD, 2001). In addition to this, prevailing level of education and infrastructure in India is sufficient enough for the same.

Technology transfer and its spillsover effect has been major objective for FDI in India. The spilslover effects can be seen due to demonstration/imitation, competition, linkages or training. Indian policy on intellectual property right was not proper, so imitation was major entry barrier for a firm with new technology. At present, a well-developed system to protect intellectual property is in place (Science and Technology Policy, 2003). High level of competition between foreign firms and domestic firms, linkage with foreign firms and training provided to employees are major sources of technological spillsover in India, resulting into positive effect on its economic growth.

A number of institutions are set up at centre level, state level and district level. Centre level institutions are Foreign Investment Promotion Board (FIPB, 1991), Foreign Investment Promotion Council (FIPC, 1996), Foreign Investment Implementation Authority (FIIA, 1999), Investment Commission (2004), Fast Track Committees (FTCs), Investment Promotion and Infrastructure Development Cell, SIA, Cabinet Committee on Foreign Investment, India Missions abroad and India Investment Centers, Project Approval Board (PAB) and Licensing Committee (LC).

State Investment Promotion Agency (SIPAs) are set up at state level and District Industries Centers at district level. These institutions play important role in determining expectation about the rights to use resources and about portioning income and assets (Davis and North, 
1971). In India, these institutions are established to enhance positive impact of FDI on Indian economy.

Against this backdrop, positive impact on economic growth is expected on account of capital accumulation for new inputs and technologies, increased know-how, managerial skills, liberal trade regime, high degree of openness of economy, better banking system and financial market, high level of human capital and technology, laws to protect intellectual property and better institutional structure.

\subsubsection{Economic Growth and Equity Market}

In Indian economy, resource mobilization function of equity market has been examined by Nagaishi (1999) using data for the period of 1981-1995. He observed that bank credit to the commercial sector is not positively correlated with the indicators of stock market developments. In this research work, an attempt is made to investigate nature of relationship between these two for different time period by adopting same methodology. Correlation matrix has been developed using data for the period of 1992-2009 (Table 1) and positive correlation has been observed. However, the deposit in banks to GDP has negative correlation with stock market indicators. Which is opposite to the complementarily hypothesis put forth by World Bank. Another important factor is new capital issue, which has been found negatively correlated with all indicators of banking system. Both observations support substitution effect between stock market investment and deposit with banks. In present scenario, it is stock market which provides more capital than banking system. Thereby, growth of Indian economy is more dependent on stock market and economic growth in India is positively correlated with equity market.

Table 1. Correlation matrix for stock market indicators and banking system indicators

\begin{tabular}{|c|c|c|c|c|}
\hline & $\begin{array}{l}\text { Liquid } \\
\text { liability } \\
\text { (M3) }\end{array}$ & $\begin{array}{l}\text { Liquid } \\
\text { liability } \\
\text { (M3-M1) }\end{array}$ & $\begin{array}{l}\text { Total Deposit } \\
\text { with banks }\end{array}$ & $\begin{array}{l}\text { Bank Credit to } \\
\text { Commercial and } \\
\text { Industrial sector }\end{array}$ \\
\hline MarketCapitalization & $\begin{array}{l}0.782002 \\
(0.001)\end{array}$ & $\begin{array}{l}0.7427573 \\
(0.001)\end{array}$ & $\begin{array}{l}\mathbf{- 0 . 3 2 6 2 7 2 0 3 1} \\
(0.001) \\
\end{array}$ & $\begin{array}{l}0.886458491 \\
(0.001)\end{array}$ \\
\hline Value Traded & $\begin{array}{l}0.457267 \\
(0.001)\end{array}$ & $\begin{array}{l}0.3873125 \\
(0.001)\end{array}$ & $\begin{array}{l}\mathbf{- 0 . 5 7 1 7 9 3 9 3 4} \\
(0.001)\end{array}$ & $\begin{array}{l}0.565995391 \\
(0.001)\end{array}$ \\
\hline TurnOver & $\begin{array}{l}0.14936 \\
(0.001)\end{array}$ & $\begin{array}{l}0.1033024 \\
(0.001)\end{array}$ & $\begin{array}{l}\mathbf{- 0 . 0 9 0 2 5 8 9 2 8} \\
(0.001)\end{array}$ & $\begin{array}{l}0.242376544 \\
(0.001)\end{array}$ \\
\hline NewCapitalIssued & $\begin{array}{l}-0.23694 \\
(0.001)\end{array}$ & $\begin{array}{l}-0.287418 \\
(0.001)\end{array}$ & $\begin{array}{l}\mathbf{- 0 . 3 5 6 7 5 2 6 0 6} \\
(0.001)\end{array}$ & $\begin{array}{l}-0.13138836 \\
(0.001)\end{array}$ \\
\hline
\end{tabular}

Source: Calculation based on data available with prowess, Business Beacon

Above discussion can be summarized as FDI inflow is positively related to economic growth and economic growth is positively related to development of stock market. Therefore, FDI 
inflow is also positively related to development of stock market. At present, FDI assist firms contribute about $25 \%$ in total market capital of stock market (Table 2).

FDI capital used by non-listed firm may not be directed to stock market but in long run it is done after listing with stock exchanges. Such listing of FDI firm results into increased market capital, consequently market depth will increase.

Table 2. Contribution of FDI Firm in Stock Market (\% of Total Market Capital)

\begin{tabular}{lllllllllll}
\hline Year & 2007 & 2008 & 2009 & 2010 & 2011 & 2012 & 2013 & 2014 & 2015 & 2016 \\
\hline Market Cap of FDI Firm & \multirow{2}{*}{18.88} & 14.9 & 13.4 & 15.1 & 13.7 & 12.5 & 22.9 & 22.4 & 27.5 & 24.4 \\
$(\%)$ & 9 & 0 & 3 & 7 & 2 & 2 & 8 & 7 & 8 \\
\hline
\end{tabular}

FDI has been allowed in all the sectors represented by constituents of stock market index (SENSEX). On this basis, portfolio of stock market index and FDI portfolio of Indian economy is expected to be very similar. This can be a possible explanation for positive correlation between FDI inflow and equity market performance. Although, FDI is equity capital investment there is also possibility of avoiding stock market route since investment is made directly into physical asset. This avoidance of stock market route may delay impact of FDI on stock market performance until listing of the firm. Stock market performance is considered as proxy measure of performance of economy. An economy with superior performance of stock market is in better position to attract foreign investor. Foreign investors making investment in host economy improves performance of stock market by increasing its depth and liquidity. Therefore, reverse causal relationship is expected between stock market performance and FDI inflow.

Therefore, the following hypotheses are proposed.

$\mathrm{H}_{1}$ : FDI inflow has positive effect on stock market performance.

$\mathrm{H}_{2}$ : Stock market performance has positive effect on FDI inflow.

\section{Exchange Rate and FDI Inflow in India}

\subsection{International Scenario}

Stock price movement affects FDI (Klein and Rosengren, 1994). Exchange rate is also important for stock price movement of a firm. Kim (2003) observed that significance of exchange rate for stock price movement increases with increase in foreign equity capital movement across the border. Such stock price movement also affects performance of stock market and exchange rate can be considered as mediator between FDI inflow and exchange rate. Exchange rate also helps in improving competitiveness of firm since it affect input and output (Joseph, 2002). Cost of input and revenue generated by output are affected by market value from where these are being procured and sold. If a firm is operating in more than one economy, then exchange rate becomes significant for cross border transactions having effect 
on profit. In this way, exchange rate has impact on stock price of firm (Yau and Nieh, 2006). This impact depends upon nature of host economy, whether export dominated or import dominated. Positive impact of exchange rate appreciation is been observed in export dominant economy while negative effect in import dominant economy (Ma and Kao, 1990). Devaluation of home currency improves export market of country (Aggarwal, 1981) by increase trading volume due to lower cost to its customer in international market. This increase in profit enhances value of firm operating in international market resulting into increased demand of money leading to higher interest rate. According to interest rate parity, exchange rate will move in a positive direction if profit increases. If profit of firm decreases, then exchange rate will move in negative direction due to decreased demand for money. Any decrease in cost of inputs increases profit of firm and increase in sales of output enhances value of firm in stock market $(\mathrm{Wu}, 2000)$.

Relationship between exchange rate and FDI depends on informational imperfection in international capital market which is root cause of costlier external financing and cheaper internal financing (Froot and Stein, 1991). Due to wealth affect, there is demand of internal financing against ownership in the firm. The devaluation of domestic currency facilitates process of acquisition by foreign investor. Claudia and Kleinert (2008) define this phenomenon as 'capital market friction hypothesis'. Another theory postulated by Claudia and Kleinert (2008) is known as 'goods market friction hypothesis' which is based on the assumptions considered by Bloniegn (1997). Blonieng assumes firms activities (manufacturing and selling) are limited to home countries, however to increase profitability firm needs to purchase technological know-how in form of firm-specific assets abroad. Value of firm for such acquisition of firm-specific asset depends on increases in profit/revenue by using these asset and sales in foreign market. Bid amount to acquire foreign asset depends upon composition of profit portfolio of firm. In this way, FDI depends on the revenue generated by firm in foreign market, which is dependent on exchange rate. Thereby FDI inflow depends on exchange rate. This hypothesis has been supported by Bloniegn (2005) for manufacturing firms using R\&D activities as proxy measure of firm-specific asset.

Yu and Cheng (2010) report effects of exchange rates on resource seeking or market seeking FDI made in China. This effect is valid for short period only however in long term the effect is ambiguous. Negative effect is observed for resource-seeking FDI and positive for market-seeking FDI. Increased volatility of exchange rate reduces FDI. Lin et al (2010) observed that volatility of exchange rate delays market-seeking FDI however it accelerates FDI for export-substituting firm. Basis of their argument is exposure to exchange rate risk, which is more for market-seeking FDI and less for export substituting FDI.

\subsection{Indian Scenario}

In a study conducted by Abdalla and Murinde (1997) it is observed that exchange rate affect stock price (performance of stock market) in India, Korea and Pakistan, however the reverse trend was observed in Philipines. Smyth \& Nandha (2001) report non-existence of relationship between stock market performance \& exchange rate in Asian countries especially India in long term. 


\section{Mll Macrothink}

International Journal of Accounting and Financial Reporting ISSN 2162-3082

The performance of Indian stock market has been analysis in reference to FII by many scholars like Agarwal (1997), Chakrabarti (2001) and Trivedi \& Nair (2003). They observe exchange rate affects stock for short-term in India. Gordon \& Gupta (2003) report negative relationship between exchange rate and stock price. Reverse causality relationship between these two variables is reported by Babu and Prabheesh (2007). Takeshi (2008) reports reverse causality relationship between FII and Indian stock market performance for a period after 2003 onward.

Utility of foreign capital in an economy is positively related with fiscal deficit. It decreases when foreign capital inflow exceeds absorptive capacity of economy. Size of current account deficit is proxy measures of absorptive capacity of an economy. In Indian economy, there is current account deficit with surplus of foreign capital flow. Size of current account deficit is low as represented in terms of percentage of GDP. Increasing inflow of foreign capital in excess of absorptive capacity may also lead to overheating of economy and asset price bubble. In this process upward pressure is created on exchange rate resulting into exchange rate appreciation. The trend of excess foreign capital inflow is shown in Figure 1.

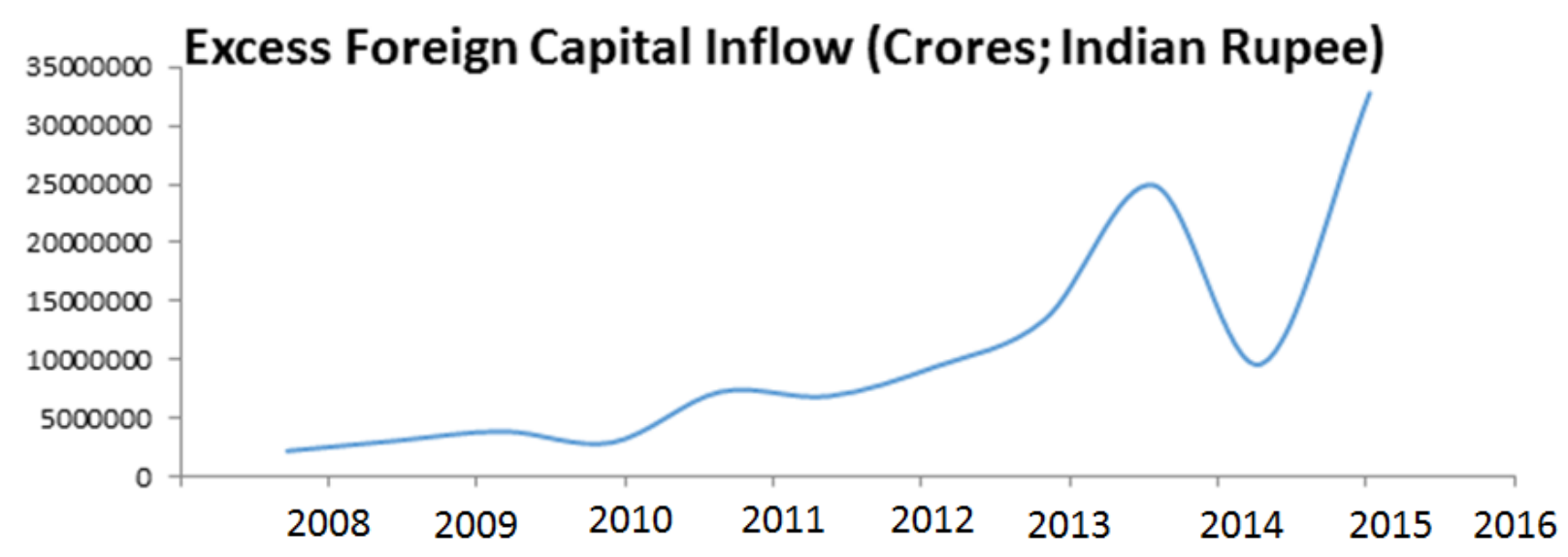

Figure 1. Excess Foreign Capital Inflow

Source: Author's own based on data provided by Business Beacon

(Dollar value is converted into rupee at annual market exchange rate provided by Business Beacon)

Reserve Bank of India (RBI) is focused on foreign capital flow to control the exchange rate and accordingly intervene in foreign exchange market. Various initiatives to boost FDI inflow is undertaken by RBI during its reformative period of 195-2009 as presented in figure 2. It is capital flow determines exchange rate movements rather than fundamentals Mohan (2007). Expectation and news about capital flow are two additional factors significant for movement of exchange rate. Significance of capital inflow is observed by impact of trade deficit on exchange rate appreciation. In Indian economy, continued trade deficit has 


\section{Macrothink \\ International Journal of Accounting and Financial Reporting \\ ISSN 2162-3082}

significant contribution towards exchange rate appreciation. Against this backdrop, foreign capital flow is important to determine exchange rate.

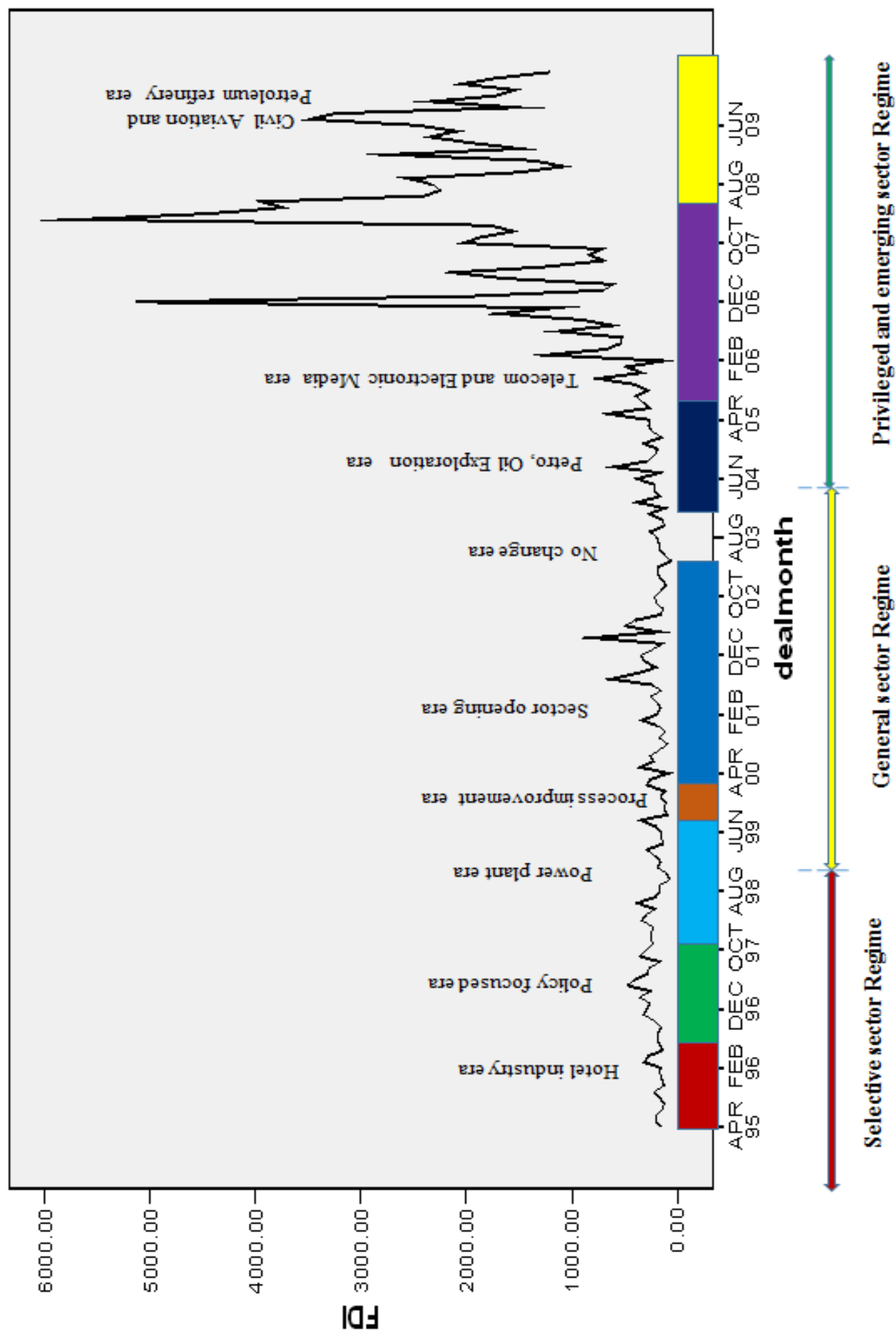

Figure 2. Different regime of FDI during reformation age (1995 to 2009) 


\section{Mll Macrothink}

International Journal of Accounting and Financial Reporting

ISSN 2162-3082

2017, Vol. 7, No. 2

Stock market performance is considered as predictor of return by foreign investors. As per expectation theory, high return in stock market attracts more foreign capital. In case of low return in stock market, foreign investor opts for other economy for investment resulting into less FDI inflow.

This study is aimed to investigate causality relationship between exchange rate and capital flow especially FDI. On the basis of above discussion, it is expected that FDI inflow have positive effects on exchange rate. Negative effects of increased exchange rates are also reported in literature with assumption that exchange rate appreciation can result into high cost, reducing trade volume. This reduction in trade volume affects economic activity negatively, resulting into output even less than average GDP per capita. This decrease in GDP per capita convey negative signal about economy reducing foreign capital inflow. Therefore in Indian economy, exchange rate appreciation reduces FDI inflow.

\section{Exchange Rate and Stock Market Performance}

\subsection{International Scenario}

Relationship between FDI and exchange rate has been dismissed on the ground that equal risk adjusted return from any part of the world through investment in form of acquisition of physical asset. Gradual fall in value of a particular currency disturb this equilibrium and makes international investment attractive. Development of modern theory of FDI dates back to 1968 (Mundell) which is mainly based on exchange rate movements. Capital movement takes place across the nations on account of cost-of-capital advantages for either domestic investee or foreign investor or both. Philosophy of cost-of-capital advantage is further supported by Hymer (1960), Vernon (1966) and Kindleberger (1969). Wealth effect is major concern of their analysis and further elaborated by Tille (2004). 'Wealth effect' is a major determinant for FDI decision (Klein and Rosengren, 1994) due to change in relative labor cost or relative wealth (Goldberg and Klein, 1998). Another reason is 'capital loss or gain' since this is highly significant for portfolio of foreign investors (Gourinchas and Rey, 2005). Cushman (1985) analysed process of internationalization and its impact of exchange rate with a focus on "where to produce, where to sell". An oligopolistic model has been proposed by Egger et al (2005) to asses real effects of exchange rates under assumption of endogenous elastic demand. General equilibrium model has been used by Russ (2007) to analyse effect of exchange rate on activities of multinational firms.

Ajayi and Mougoue (1996) conducted study for eight advance economies to observe impact of exchange rate on stock performance. They observe that increase in stock performance (as evident from stock price) has negative effect for short-term however for long-term this effect is positive on domestic currency. Devaluation of home currency effects stock market performance negatively in short-term as well as long-term period. Pentecost (2000) analysed G7 countries and report no causality relationship between stock market performance and exchange rate. This study has been also supported by Niesh and Lee (2001). Kim (2003) reports negative relationship between stock price and exchange rate. Stock market performance and exchange rate do not exhibit co-integration (Doong et al, 2005; Ozair, 2006). 


\section{Mll Macrothink}

International Journal of Accounting and Financial Reporting

ISSN 2162-3082

2017, Vol. 7, No. 2

Co-integration between exchange rate and large cap stock has been observed by Vygodina (2006).

\subsection{Indian scenario}

Stock performance is driven by firm performance generally measured in terms of profit or sales, which is generated from its operations. Firm operating in more than one economy, there is impact of exchange rate on its profit. The nature of effects depends on economy source for its inputs and economy to offer market of its outputs. Stock price of firm reflects its valuation as per investors' perception, which is largely dependent of its performance. In this way, it is concluded that exchange rate affects stock price of firm and a number of studies are reported in literature. In this research work, this argument is applied to Indian economy and extended to stock market performance. On average $20 \%$ of the firms operate in more than one economy so their profitability is exposed exchange rate movements. For trading firm, effect of exchange rate movement on profitability is more significant. Stock market performance is an overall indicator of an economy which depends on performance of firms. Therefore, exchange rate affects performance of stock market. This effect is favourable for exchange rate movement increasing profit otherwise negative. Therefore, it is an interesting issue to investigate effect of exchange rate on overall performance of stock market. In India, majority of the firms are importing products (on the basis of continued trade deficit) and positive impact is expected.

This analysis is incomplete without considering effect of stock market performance on exchange rate is carried on.

This research work is focused on investigation of effects of stock market performance on exchange rate. One can expect appreciation of exchange rate if stock performance is high and depreciation in case of low. Indian stock market performance is high and appreciation of exchange rate is expected.

\section{Dataset}

This analysis is focused on the relation between FDI inflow, stock market performance and exchange rate. It is important to determine direction and causality of relation between these three variables. Therefore, time series analysis (co-integration test) enables to investigate such relationships. Time series of FDI inflow is formed by obtaining monthly data from website of Department of Industrial Policy and Promotion (DIPP) and Business Beacon between Jan 2007 to April 2016. To analyse stock market performance BSE SENSEX is considered as benchmark index and its monthly closing price is obtained from yahoo finance website. Various sources of time series data is presented in Table 3. 


\section{Mll Macrothink}

International Journal of Accounting and Financial Reporting

Table 3. Sources of Data on FDI, SENSEX and Exchange Rate

\begin{tabular}{|c|c|c|c|}
\hline Variable & $\begin{array}{l}\text { Period } \\
\text { /Time } \\
\text { series }\end{array}$ & Expression & Sources \\
\hline $\begin{array}{l}\text { FDI } \\
\text { inflow }\end{array}$ & Monthly & US\$ (Mn) & $\begin{array}{l}\text { Business Beacon and } \\
\text { http://www.dipp.nic.in/fdi_statistics/india } \\
\text { fdi_index.htm }\end{array}$ \\
\hline $\begin{array}{l}\text { BSE } \\
\text { SENSEX }\end{array}$ & Monthly & $\begin{array}{l}\text { Closing index on last } \\
\text { trading day of the } \\
\text { month(base } 1978-79= \\
100 \text { ) }\end{array}$ & $\begin{array}{l}\text { http://in.finance.yahoo.com/q/hp?s=\%5EB } \\
\text { SESN\&g=m\&a=00\&b=1\&c=2004\&d=10 } \\
\& \mathrm{e}=7 \& \mathrm{f}=2010\end{array}$ \\
\hline $\begin{array}{l}\text { Exchange } \\
\text { Rate }\end{array}$ & Monthly & $\begin{array}{l}\text { Base currency }=\text { US\$ } \\
\text { Target currency = } \\
\text { Indian rupee }\end{array}$ & $\begin{array}{l}\text { http://www.X-rates.com/cgi-bin/hlookup.cg } \\
\text { i }\end{array}$ \\
\hline
\end{tabular}

\section{Methodology}

Time series analysis is performed with help of statistical software STATA11. Characteristics of FDI inflow, SENSEX and exchange rate are presented by plotting time series, spectral density function, spectral distribution function, correlodiagram, cross correlodiagarm and partial autocorrelodiagram in Figures 3.1 and 3.2. Unit roots tests are performed to check order of integration of each of time series. This test also ensures validity of conducting multivariate co-integration analysis (Johansen, 1998, 1991) since it is valid only if time series are integrated with same order. For this purpose, three different approaches of unit roots test i.e. Augmented Dickey-Fuller (ADF), DF-GLS test, and Philips-Perron (PP) are performed for both level and first difference of time series. To determine optimal lag length, Vector Auto Regression (VaR) selection order criteria (Post estimation) i.e. LR, Akaike Information Criterion (AIC) and Schwartz Baysian Information Criterion (SBIC) are applied. A diagnostic test of Granger-Causality (Granger, 1981; Engle and Granger, 1987) is performed for VaR to establish relationship among time series of different variables. To get dynamic forecast and impulse response function, Vector Error Correction Model (VECM) has been used. All these tests are performed using STATA11. 


\section{Macrothink}

International Journal of Accounting and Financial Reporting ISSN 2162-3082
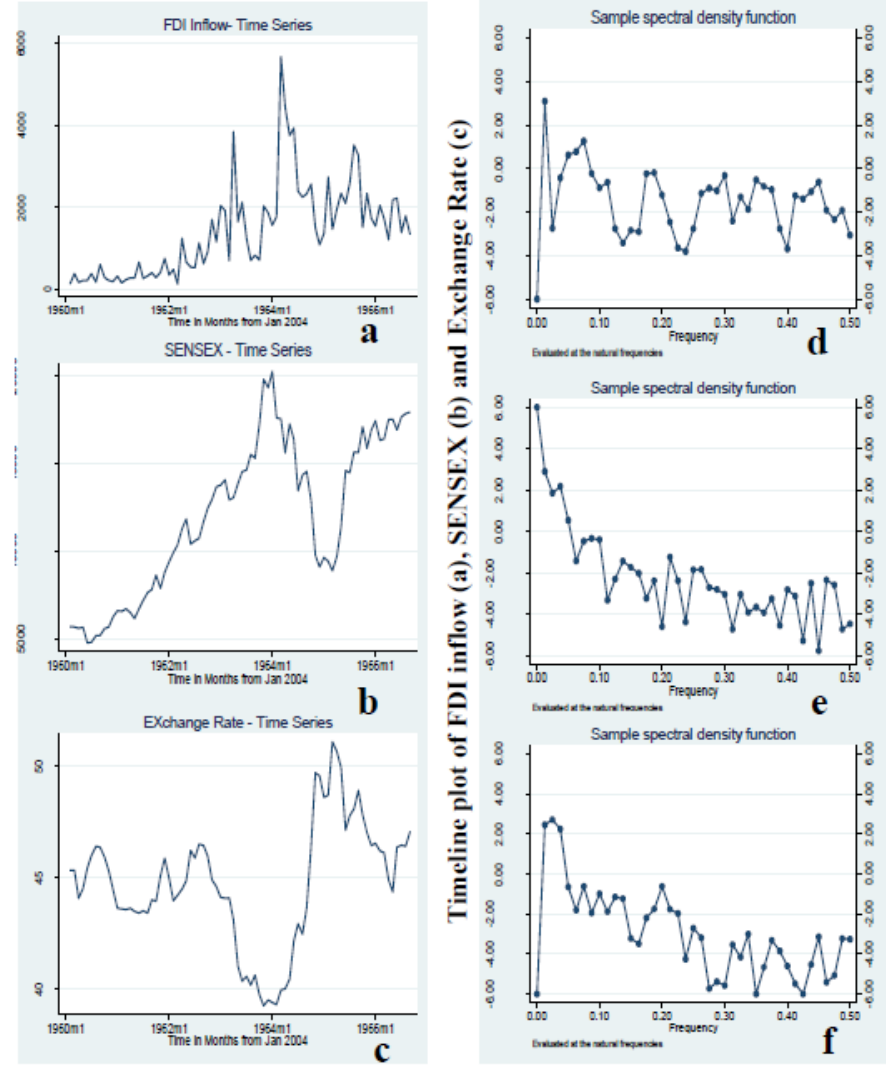

2017, Vol. 7, No. 2

Figure 3.1. Time line, Spectral Density Function and Spectral Density Distributions of FDI Inflow, SENSEX and Exchange Rate
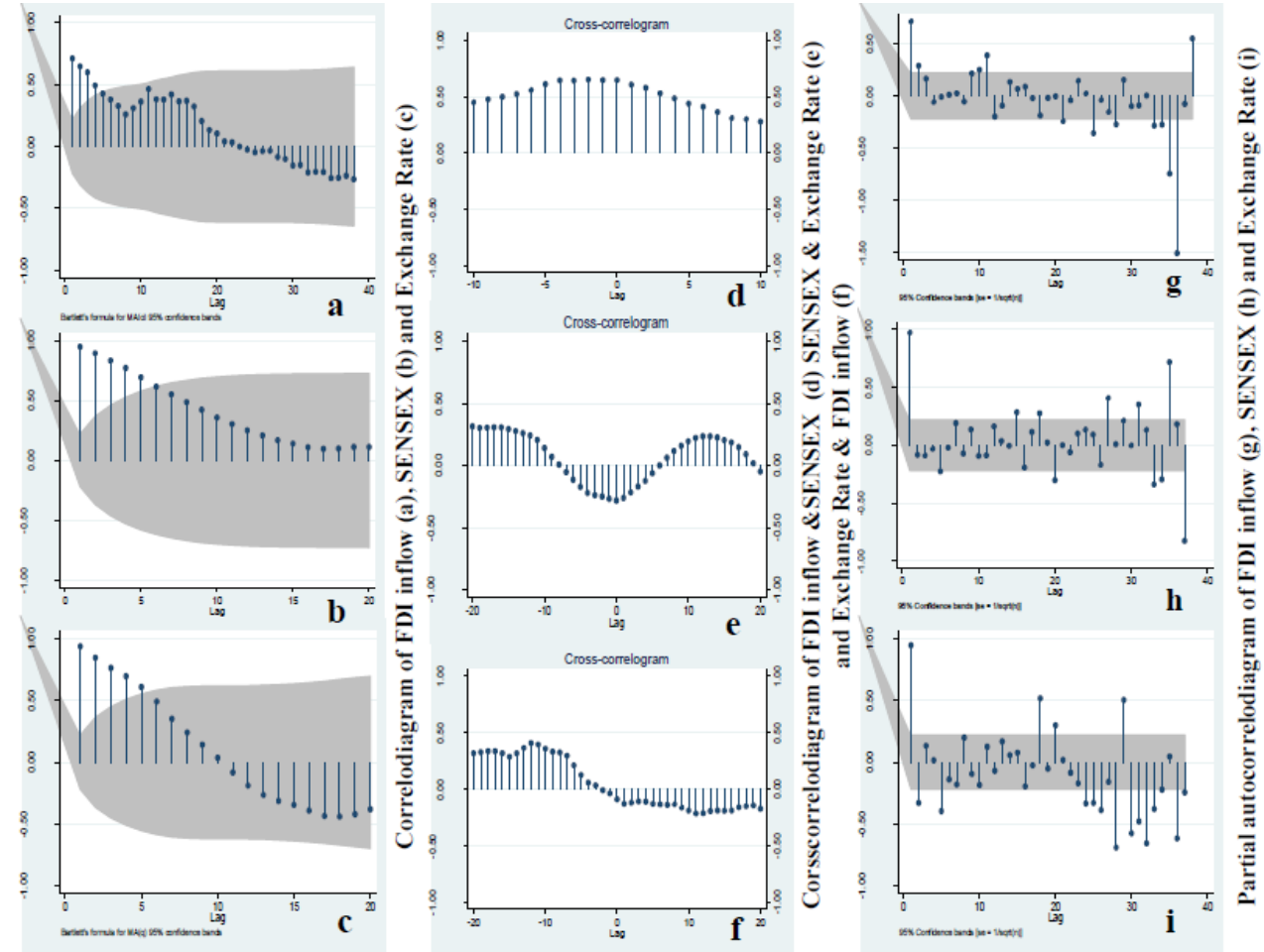

Figure 3.2. Correlodiagram, Corss Correlodiagram and Partial Auto Correlodiagram (PAC) of FDI Inflow, SENSEX and Exchange Rate 


\section{Il Macrothink \\ International Journal of Accounting and Financial Reporting \\ ISSN 2162-3082 \\ 2017, Vol. 7, No. 2}

\section{Results and Discussion}

\subsection{Presence of Unit Roots in Time Series}

Monthly time series of FDI inflow, SENSEX and exchange rate have unit roots at level. It means that there is more than one trend exhibited by time series of monthly FDI inflow, SENSEX and exchange rate. This is in line with the objective of government. Government policy has objective to increase FDI inflow. FDI inflow in India became significant only after financial liberalization in 1991. It has been almost stagnant during initial years (Figure 3). To improve FDI inflow, a number of measures as policy reforms, have been considered by Indian government. These measures are broadly classified as opening up of new industry for FDI and increasing the upper cap on FDI at firm level. Such reforms helped in increasing FDI inflow and in this way, trend of FDI inflow is changed. Therefore, more than one trend is expected in FDI inflow in India and which is reflected in results. Financial crisis in 2008 was global phenomenon, having adverse effect on stock markets across the globe and Indian stock market was not exception to this. Prior to financial crisis, Indian stock market has shown bullish behavior (SENSEX crossed 20000) which get transformed into bearish (SENSEX dip below 5000) as a consequence of financial crisis. Post financial crisis, SENSEX has been hovering above 20000, which can be taken as signal for reverting to bullish behavior. In this way, performance of Indian stock market has exhibited more than one trend and presence of unit roots in time series of monthly SENSEX is considered empirical evidence for the same. Indian government has no policy towards fixed exchange rate and it gets determined by supply and demand conditions in foreign exchange market. These conditions vary with time and trend possessed by the exchange rate also follow market trend, which is not constant always. In this way, time series of monthly exchange rate exhibits more than one trend which is supported by the presence of unit roots in time series.

First difference of these three time series have no unit roots (Table 4.1), so they exhibit only one trend. The shocks to these variables are temporary in nature and dissipate very soon. In case of FDI inflow, SENSEX and exchange rate, financial crisis can be considered as shock during mid 2008. Now all of these series have been reverted to their long run mean. Therefore, these series are integrated with same order. 
Table 4.1. Results of Unit Roots Tests

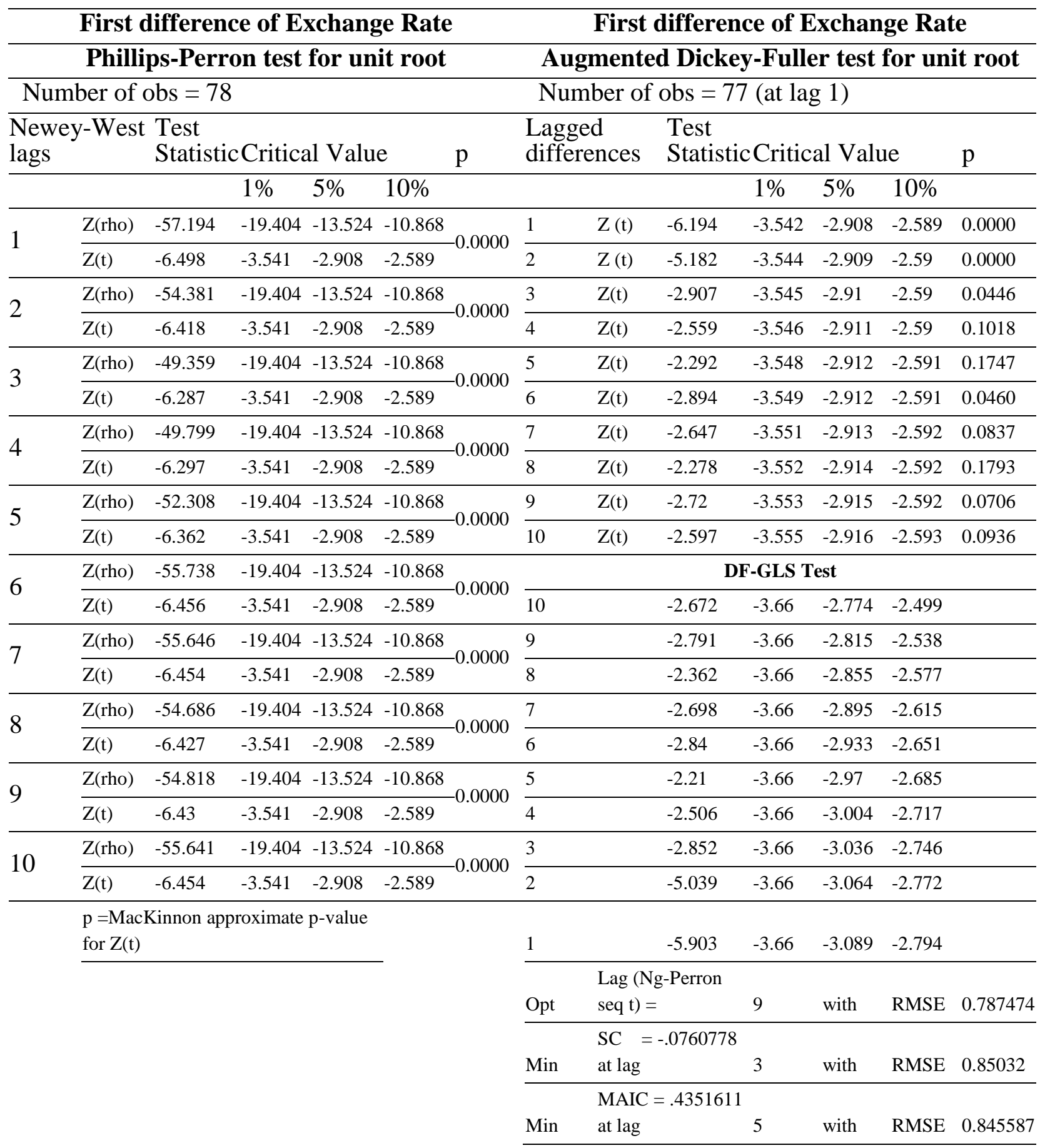

\subsection{Optimal Lag Length}

Optimal lag length is important for policy maker. It tells how far, effect of change in one variable is observed on another variable. FDI inflow is long term investment phenomenon and it is expected to have longest lag length. On other hand, SENSEX and exchange rates are determined by prevailing market conditions and transactions taken place on each trading day. Therefore, lag length should be minimum (Zero). By applying three selection criteria, two 
probable value of optimal lag length i.e. 10 months and 0 month are observed (Table 4.2). These two values of optimal lag length can be attributed to the presence of long term impact variable i.e. FDI inflow. For policy making decision, it can be interpreted that effect of any change in FDI inflow will be observed in stock market or foreign currency market after ten months and vice versa. But effect of change in SENSEX is observed in foreign currency market instantly and vice-versa.

\subsection{Granger Causality Wald Test}

Output presented in Table 4.3, exhibits empirical evidences of statistically significant reverse causality relationship between change in FDI inflow, change in SENSEX and change in exchange rate. The test results of hypotheses postulated are presented in Table 4.4.

Table 4.2. VaR Selection Order Criteria (Post estimation)

Sample Period: Jan 2004 - Aug 2010

\begin{tabular}{lllllllll}
\hline Lag & LL & LR & df & P & FPE & AIC & HQIC & SBIC \\
\hline $\mathbf{0}$ & -1229.85 & & & & $6.6 \mathrm{e}+11$ & 35.7347 & 35.7732 & 35.8318 \\
\hline $\mathbf{1}$ & -1217.24 & 25.207 & 9 & 0.003 & $6.0 \mathrm{e}+11$ & 35.6302 & 35.7844 & 36.0188 \\
\hline $\mathbf{2}$ & -1212.76 & 8.9635 & 9 & 0.441 & $6.8 \mathrm{e}+11$ & 35.7612 & 36.031 & 36.4411 \\
\hline $\mathbf{3}$ & -1210.34 & 4.839 & 9 & 0.848 & $8.3 \mathrm{e}+11$ & 35.9519 & 36.3373 & 36.9233 \\
\hline $\mathbf{4}$ & -1197.68 & 25.317 & 9 & 0.003 & $7.5 \mathrm{e}+11$ & 35.8459 & 36.3469 & 37.1086 \\
\hline $\mathbf{5}$ & -1191.86 & 11.639 & 9 & 0.234 & $8.3 \mathrm{e}+11$ & 35.9381 & 36.5547 & 37.4922 \\
\hline $\mathbf{6}$ & -1184.23 & 15.271 & 9 & 0.084 & $8.8 \mathrm{e}+11$ & 35.9776 & 36.7098 & 37.8232 \\
\hline $\mathbf{7}$ & -1165.28 & 37.899 & 9 & 0.000 & $6.8 \mathrm{e}+11$ & 35.6892 & 36.5371 & 37.8262 \\
\hline $\mathbf{8}$ & -1160.83 & 8.8901 & 9 & 0.447 & $8.0 \mathrm{e}+11$ & 35.8213 & 36.7847 & 38.2496 \\
\hline $\mathbf{9}$ & -1157.75 & 6.1635 & 9 & 0.723 & $1.0 \mathrm{e}+11$ & 35.9928 & 37.0718 & 38.7126 \\
\hline $\mathbf{1 0}$ & -1135.64 & 44.216 & 9 & 0.000 & $7.2 \mathrm{e}+11$ & 35.6129 & 36.8075 & 38.6241 \\
\hline
\end{tabular}

Endogenous: FDIInflowd1, Sensexd1 ExchangeRated1 Exogenous: Constant

Table 4.3. Granger Causality Wald tests

\begin{tabular}{lllll}
\hline Equation & Excluded & $\chi^{2}$ & df & Prob $>\boldsymbol{\chi}^{2}$ \\
\hline FDIInflowd1 & Sensexd1 & 33.49 & 10 & 0.000 \\
\hline FDIInflowd1 & ExchangeRated1 & 22.184 & 10 & 0.014 \\
\hline FDIInflowd1 & All & 40.702 & 20 & 0.004 \\
\hline Sensexd1 & FDIInflowd1 & 23.597 & 10 & 0.009 \\
\hline Sensexd1 & ExchangeRated1 & 32.589 & 10 & 0.000 \\
\hline Sensexd1 & All & 45.827 & 20 & 0.001 \\
\hline ExchangeRated1 & FDIInflowd1 & 25.109 & 10 & 0.005 \\
\hline ExchangeRated1 & Sensexd1 & 40.872 & 10 & 0.000 \\
\hline ExchangeRated1 & All & 65.677 & 20 & 0.000 \\
\hline
\end{tabular}




\section{MInstitute Macrothink $^{\text {Int }}$}

International Journal of Accounting and Financial Reporting

ISSN 2162-3082

2017, Vol. 7, No. 2

Table 4.4. Test Results of hypotheses postulated on FDI inflow, foreign exchange rate and equity market

\section{Findings}

1. FDI inflow is positively related to equity market performance.

2. Stock market performance is positively related to FDI inflow.

3. FDI inflow has positive effect on foreign exchange rate in India.

4. Appreciation in exchange rate reduces FDI inflow in Indian economy.

5. Exchange rate appreciation increases performance of stock market.

6. Stock market performance is positively related to exchange rate.

\section{Conclusions and Policy Implications}

India is making new initiatives to increase FDI inflow in anticipation of higher economic growth reflected by stock market performance. In process of FDI, fund flows across border increases significance of exchange rate for both foreign investor and host economy. Therefore, this study is focused on three macro-economic variables i.e. FDI inflow, stock market performance and exchange rate. These variables are considered as input for policy reforms to accomplish underlying objectives. Theory of 'Impossible Trinity' or 'Policy Trilemma' is widely accepted macroeconomic framework to asses ability of an economy to accomplish only two out of three policy objectives i.e., financial integration, monetary and exchange rate stability.

This framework is used in this research work for policy implications based on relationship between these three variables. This is done by establishing relationship of each variable with different policies. FDI inflow supplements supply of domestic capital for long term. In other words, using foreign capital to supplement domestic supply of capital to firm is considered as objective of fiscal policy. SENSEX is performance indicator of stock market, which is equity finance wing of Indian financial system. Another wing of Indian financial system is banking sector extending credit (debt capital) mainly to commercial and industrial sector. Reserve Bank of India (RBI) controls supply of money through banking system and there is interplay between banking and stock market system. In India, substitution effect has been observed, thereby, performance of stock market can be considered as one objective of monetary policy.

Now, identification of least significant relationship between these variables suggests priorities of policies to achieve underlying objectives. Impact of change in exchange rate on changes in FDI inflow is least significant followed by impact of changes in FDI inflow on changes in SENSEX. Third least significant relationship is between changes in FDI inflow and change in exchange rate.

Against this backdrop, it is recommended that SENSEX should be on priority followed by exchange rate. Accordingly monetary policy and exchange rate are highly significant for policy maker. Improvement of stock market and favourable exchange rate increases FDI inflow. Stock market performance depends on transactions by investors. These investors are regulated only, not controlled. RBI controls supply of foreign currency in India by assessing 
supply conditions of market and consequently intervening in foreign exchange market. In other words, exchange rate gets controlled by controlling supply of foreign currency in domestic market. Therefore, target band of exchange rate is attained by controlling supply of foreign currency. At present, exchange rate is determined by market conditions only, so fixed exchange rate regime is not suitable. This may results into shock to market however a step can be taken in this direction by implementing target band of exchange rate. Initially wider exchange rate band is expected and to be narrowed gradually. In case of adverse impact on Indian economy, widening this band is very much similar to market determined exchange rate regime.

\section{References}

Abdalla, I.S.A., \& Murinde, V. (1997). Exchange rate and stock prices interactions in emerging financial markets: evidence on India, Korea, Pakistan and the Philippines. Applied Financial Economics, 7, 25-35.

Agarwal, R. (1981). Exchange Rates and Stock Prices: A Study of the United States Capital Markets under Floating exchange rates. Akron Business and Economic Review, 12(1), 7-12.

Agarwal, R. (1997). Survival of Firms Over the Product Life Cycle. Southern Economic Journal, 63(3), 571-585.

Aitken, B., \& Harrison, A. (1999). Do Domestic Firms Benefit from Direct Foreign Investment ? Evidence from Venezuela. American Economic Review, 89(3), 605-618.

Ajayi, R. A., \& Mougoue, M. (1996). On the Dynamic Relation between Stock Prices and Exchange Rates. Journal of Financial Research, 19, 193-207.

Alfaro, L., Chanda, A., Kalemli-Ozcan, S., \& Sayek, S. (2004). FDI and Economic Growth: The Role of Local Financial Markets. Journal of International Economics, 64(1), 89-112.

Babu, M. S., \& Prabheesh, K. (2007). Causal Relationships between Foreign Institutional Investments and stock returns in India. International Journal of Trade and Global Markets, $1(3), 259-265$.

Bagchi, A. K. (1972). Private Investment in India 1900-1939. Cambridge University Press, Cambridge.

Blonigen, B. A. (1997). Firm-Specific Assets and the Link between Exchange Rates and Foreign Direct Investment. American Economic Review, 87(3), 447-65.

Blonigen, B., A. (2005). A Review of the Empirical Literature on FDI Determinants. National Bureau of Economic Research, Working Paper No. 11299, April. Cambridge, MA: NBER.

Blonigen, B. A., \& Wang, M. (2004). Inappropriate Pooling of Wealthy and Poor Countries in Empirical FDI Studies. National Bureau of Economic Research, Working Paper No. 10378, April. Cambridge, MA: NBER. 


\section{MInstitute ${ }^{\text {Mit }}$}

International Journal of Accounting and Financial Reporting

ISSN 2162-3082

Boddewyn, J. J. (1985). Advertising self-regulation: Private Government and Agent of Public Policy. Journal of Public Policy and Marketing, 4, 129-141.

Borensztein, E., De-Gregorio, J., \& Lee, J.W. (1998). How Does Foreign Direct Investment Affect Economic Growth?. Journal of International Economics, 45, 115-135.

Borghesi, S., \& Giovannetti, G. (2003). The Role of Institutional Set-Up in the Success of FDI: Do Countries Attracting FDI Grow at Higher Rates?. Preliminary draft, October 2003. In Ilhan, O. (Ed.), Foreign Direct Investment-Growth Nexus: A Review of the Recent Literature (Vol. 4, No. 2, 2007). International Journal of Econometrics and Quantitative Studies.

Chakrabarti, R. (2001, Oct-Dec.). FII Flows to India: Nature and Causes. Money and Finance, 2(7).

Chakraborty, C., \& Nunnenkamp, P. (2008). Economic Reforms, FDI, and Economic Growth in India: A Sector Level Analysis. World Development, 36(7), 1192-1212.

Claudia, M. B., \& Kleinert, J. (2008). Exchange Rates and FDI: Goods versus Capital Market Frictions. The World Economy, 31, 1185-1207.

Cushman, D. O. (1985). Real Exchange Rate Risk, Expectations, and the Level of Direct Investment. Review of Economics and Statistics, 67(2), 297-308.

Davis, Lance E., \& North, D. (1971). Institutional Change and American Economic Growth. Cambridge University Press.

Department of Science and Technology. (2003). Science and Technology Policy. Department of Science and Technology, Govt of India.

Doong, S.-C., Yang, S.Y., \& Wang, A. T. (2005). The Emerging Relationship and Pricing of Stocks and Exchange Rates: Empirical Evidence from Asian Emerging Markets. Journal of American Academy of Business, 7(1), 118-123.

Durham, B. (2004). Absorptive Capacity and the Effects of Foreign Direct Investment and Equity Foreign Portfolio Investment on Economic Growth. European Economic Review, 48(2), 285-306.

Egger, H. P., Egger, \& M. Ryan. (2005). Exchange Rate Effects on Complex FDI: Theory and Evidence, University of Munich (mimeo).

Engle, Robert F., \& Granger, Clive W. J. (1987). Co-integration and error correction: Representation, estimation and testing. Econometrica, 55(2), 251-276.

Encarnation, D. J., \& Wells, L. T. (1985). Sovereignty en Garde: Negotiating with Foreign Investors. International Organization, 39(1), 47-78.

Froot, K. A., \& Stein, J. C. (1991). Exchange Rates and Foreign Direct Investment: An Imperfect Capital Markets Approach. The Quarterly Journal of Economics, 106(4), 1191-1217. 


\section{$\triangle$ Macrothink}

International Journal of Accounting and Financial Reporting ISSN 2162-3082

Goldberg, L. S., \& Klein, M. (1998). Foreign Direct Investment, Trade, and Real Exchange Rate Linkages in Developing Countries. In R. Glick (Ed.), Managing Capital Flows and Exchange Rates: Lessons from the Pacific Basin. Cambridge: Cambridge University Press, pp. 73-100.

Goldsmith, R.W. (1969). Financial Structure and Development. New Haven, CT: Yale University Press.

Gordon, J., \& Gupta, P. (2003). Portfolio Flows into India: Do Domestic Fundamentals Matter?. IMF Working Paper Number, WP/03/02, 217-229.

Gourinchas, P. O., \& Rey, H. (2005). International Financial Adjustment. National Bureau of Economic Research, Working Paper No. 11155 (Cambridge, MA: NBER).

Granger, C. (1981). Some Properties of Time Series Data and Their Use in Econometric Model Specification. Journal of Econometrics, 16, 121-130.

Hermes, N., \& Lensink, R. (2003). Foreign Direct Investment, Financial Development and Economic Growth. The Journal of Development Studies, 40(1), 142-163.

Hymer, S. H. (1960). The International Operations of National Firms: A Study of Direct Foreign Investment. PhD Dissertation, Published posthumously, The MIT Press, 1976. Cambridge.

Johansen, S. (1988). Statistical Analysis of Cointegration Vectors. Journal of Economic Dynamics and Control, 12, 231-254.

Johansen, S. (1991). Estimation and Hypothesis Testing of Cointegration Vectors in Gaussian Vector Autoregressive Models. Econometrica, 59, 1551-1580.

Joseph, N. (2002). Modelling the Impacts of Interest Rate and Exchange Rate Changes on UK Stock Returns, Derivatives Use. Trading and Regulation, 7(4), 306-323.

Khawar, M. (2005). Foreign Direct Investment and Economic Growth: A Cross-Country Analysis. Global Economic Journal, 5(8). Retrieved August 8, 2010, from http://www.bepress.com/gej>

Kindleberger, C. (1969). American Business Abroad: Six Lectures on Direct Investment. New Haven: Yale University Press.

Kim, K. (2003). Dollar Exchange Rate and Stock Price: Evidence from Multivariate Cointegration and Error Correction model. Review of Financial Economics, 12, 301-313.

Klein, M. W., \& Rosengren, E. (1994). The Real Exchange Rate and Foreign Direct Investment in the United States: Relative Wealth vs. Relative Wage Effects. Journal of International Economics, 36(3-4), 373-89.

Levine, R., \& Zevros, S. (1998). Stock Markets, Banks and Economic Growth. American Economic Review, 88(3), 537-558. 


\section{I Macrothink}

International Journal of Accounting and Financial Reporting ISSN 2162-3082 2017, Vol. 7, No. 2

Lim, E.-G. (2001). Determinants of, and the Relation between, Foreign Direct Investment and Growth: A Summary of the Recent Literature. Working Paper 01/ 175. International Monetary Fund, Washington, DC.

Lin, Hui-lin, \& Lin, E. S. (2010). FDI, Trade, and Product Innovation: Theory and Evidence. Southern Economic Journal, 77(2), 434-464.

Lipsey, R. E. (2002). Home and Host Country Effects of FDI. NBER Working Paper 9293, National Bureau of Economic Research, Cambridge, MA.

Ma, C. K., \& Kao, G. W. (1990). On Exchange Rate Changes and Stock Price Reactions. Journal of Business Finance and Accounting, 17, 441-449.

McKinnon, R. (1973). Money and Capital in Economic Development. Brookings Institute, Washington.

Mohan, R. (2007). India's Financial Sector Reforms: Fostering Growth While Containing Risk. Reserve Bank of India Bulletin, December.

Mundell, R. A. (1968). International Economics. New York: Macmillan.

NCAER. (2009). FDI in India and its Growth Linkages. National Centre for Applied Economic Research, New Delhi.

Nagaishi, M. (1999). Stock Market Development and Economic Growth: Dubious Relationship. Economic and Political Weekly, 34(29), 2004-2012.

Niesh, C. C., \& Lee, C. F. (2001). Dynamic Relationship between Stock Prices and Exchange Rates for G-7 Countries. The Quarterly Review of Economics and Finance, 41, 477-490.

OECD. (2001). OECD Review on Foreign Direct Investment OECD.

OECD. (2002). Foreign Direct Investment for Development - Maximising Benefits, Minimising Costs. OECD, Paris.

Ozair, A. (2006). Causality between Stock prices and Exchange Rates: A Case of The United States. Florida Atlantic University, Master of Science Thesis.

Pentecost, E. J., \& Morley, B. (2000). Common Trends and Cycles in G-7 Countries Exchange Rates and Stock Prices. Applied Economics Letters, 7, 7-10.

Rajan, R. G., \& Zingales, L. (1998). Financial Dependence and Growth. American Economic Review, 88(3), 559-586.

Romer, P. (1993). Idea Gaps and Object Gaps in Economic Development. Journal of Monetary Economics, 32, 543-573.

Russ, K. (2007). The Endogeneity of the Exchange Rate as a Determinant of FDI: A Model of Money, Entry, and Multinational Firms. Journal of International Economics, 71(2), 344-72. 


\section{MInstitute Macrothink $_{\text {Int }}$}

International Journal of Accounting and Financial Reporting

ISSN 2162-3082

Schumpeter, Joseph A. Theorie der Wirtschaftlichen Entwicklung. Leipzig: Dunker \& Humblot, 1912. [The Theory of Economic Development, 1912, translated by Redvers Opie. Cambridge, MA: Harvard University Press, 1934.]

Shaw, E. (1973). Financial Deepening in Economic Development. New York: Oxford University Press.

Smyth, R., \& Nadha, M. (2003). Bivariate Causality between Exchange Rates and Stock Prices in South Asia. Applied Economics Letters, 10, 699-704.

Takeshi, I. (2008). The Causal Relationships in Mean and Variance between Stock Returns and Foreign Institutional Investment in India. IDE Paper Discussion, No. 180.

Tille, C. (2004). Financial Integration and the Wealth Effect of Exchange Rate Fluctuations. Federal Reserve Bank of New York (mimeo).

Trivedi, P., \& Nair, A. (2003). Determinants of FII Investment Inflow to India. 5th Annual conference on Money and Finance in The Indian Economy (January 30 - February 1, 2003), Indira Gandhi Institute of Development Research.

Vernon, R. (1966). International Investment and International Trade in the Product Cycle. Quarterly Journal of Economics, 80(2), 190-207.

Vygodina, A. V. (2006). Effects of Size and International Exposure of the US Firms on the Relationship between Stock Prices and Exchange Rates. Global Finance Journal, 17, 214-223.

Wang, Z., \& Swain, N. (1995). The Determinants of Foreign Direct Investment in Transforming Economies: Empirical Evidence from Hungary and China. Weltwirtschaftliches Archiv, 129, 359-381.

Wheeler, D., \& Mody, A. (1992). International Investment Location Decisions: The case of US firms. Journal of International Economics, 33, 57-76.

Wu, Y. (2000). Stock Prices and Exchange Rates in a VEC model- The Case of Singapore in the 1990s. Journal of Economics and Finance, 24(3), 260-274.

Wurgler, J. (2000). Financial Markets and the Allocation of Capital. Journal of Financial Economics, 58, 187-214.

Yau, H. Y., \& Nieh, C. C. (2006). Interrelationships among Stock Prices of Taiwan and Japan and NTD/Yen exchange rate. Journal of Asian Economics, 17, 535-552.

Yu, J., \& Yao, C. (2010). An Empirical Study of the Effects of RMB Exchange Rate on China's Inflows of FDI. Journal of International Economic Studies, 24, 99-111. 


\section{Macrothink \\ International Journal of Accounting and Financial Reporting ISSN 2162-3082 2017, Vol. 7, No. 2}

Notes

Note 1. Based on the data from Business Beacon

Note 2. Based on the data from Business Beacon

Note 3. Based on the data from Business Beacon

Note 4. Calculation based on data from Business Beacon

Note 5. India's human development index 2007

Note $6 . \quad$ TRAI $\quad$ press release (http://sify.com/finance/teledensity-in-india-touches-51-05-percent-news-default-kd3ukcjcjfj. html)

\section{Copyright Disclaimer}

Copyright for this article is retained by the author(s), with first publication rights granted to the journal.

This is an open-access article distributed under the terms and conditions of the Creative Commons Attribution license (http://creativecommons.org/licenses/by/4.0/) 